\title{
ANALISIS JALUR HUBUNGAN DURASI TIDUR DAN ASUPAN PROTEIN PADA IBU HAMIL ANEMIA DENGAN KEJADIAN BERAT BAYI LAHIR RENDAH
}

\author{
Analysis of association between Sleeping Duration and Protein Intake in Anemic Pregnant Women \\ toward Incidence of Low Birth Weight Baby
}

Sufia Fitriani, Eti Poncorini Pamungkasari, Suminah

Program Studi IImu Gizi, Pascasarjana Universitas Sebelas Maret, Surakarta, Indonesia E-mail: sofie.foodtech08ub@gmail.com

\begin{abstract}
Anemia is highly prevalent among Indonesian community, especially in pregnant women. Sleep duration and poor sleep patterns when someone is pregnant mayincrease therisk factors that affect the outcome of pregnancy. Protein requirements for pregnant women will increase as increasing gestational age. Lack of protein intake maycause low birth weight.The purpose of this study was to analyze the correlationof sleeping duration and protein intake in anemic pregnant women with the incidence of low birth weight babies.The study used a case control design. The subject of the study was anemic pregnant women in Sukoharjo who have been gaving birth from 2016 to 2018. Subjects wereselected using purposive sampling. Case was those who delivered normal baby's weight and case was those who delivered low bird weight baby. 74 subjcts were in control group and 37 subjects were in case group.Sleeping duration was measured during sleep at night per hour and the quality of sleeping using PSQI from. Path analysiswasused to evaluate the association. The results showed that the association of sleeping duration of anemic pregnant women with incidence of LBW was not significant $(p=0,285)$; protein intake withincidence of $L B W$ was significant $(p=0,019)$, and sleep quality anemic pregnant women with incidence of LBW was not significant $(p=0,379)$. There is no significant direct and indirect associations (through sleep quality) of sleeping duration among anemic pregnant women withincidence of LBW, there is a significant association of protein intake in anemic pregnant women with incidence of LBW, and there is no significant indirect association (through sleep quality) of protein intake in anemic pregnant women with incidence of LBW babies.
\end{abstract}

Keywords: sleeping duration, protein intake, sleep quality, anemic pregnant women, low birth weight

\section{ABSTRAK}

Anemia banyak terjadi pada masyarakat terutama pada ibu hamil. Durasi tidur dan buruknya pola tidur pada saat seseorang sedang hamil dapat meningkatkan faktor resiko yang memengaruhi hasil akhir kehamilan. Kebutuhan protein untuk ibu hamil akan semakin meningkat seiring dengan bertambahnya usia kehamilan. Kekurangan asupan protein dapat menyebabkan kejadian berat badan lahir bayi rendah.Tujuan penelitian ini untuk menganalisis hubungan durasi tidur dan asupan protein pada ibu hamil anemia terhadap kejadian berat bayi lahir rendah.Rancangan penelitian menggunakan desain case control. Sampel penelitian adalah ibu hamil anemia di Sukoharjo yang melahirkan tahun 2016-2018. Pemilihan sampel dengan menggunakan purposive sampling. Analisis data menggunakan path analysis. Hasil path analysis untuk hubungan durasi tidur ibu hamil anemia dengan kejadian BBLR tidak bermakna $(p=0,285)$, asupan protein ibu hamil anemia dengan kejadian BBLR bermakna $(p=0,019)$, dan hubungan kualitas tidur ibu hamil anemia terhadap kejadian BBLR tidak bermakna $(p=0,379)$. Tidak ada hubungan signifikan secara langsung maupun tidak langsung (melalui kualitas tidur) durasi tidur ibu hamil anemia dengan kejadian BBLR, ada hubungan signifikan dari asupan protein ibu hamil anemia dengan kejadian BBLR, dan tidak ada hubungan signifikan secara tidak langsung (melalui kualitas tidur) dari asupan protein ibu hamil anemia dengan kejadian BBLR.

Kata kunci: durasi tidur, asupan protein, kualitas tidur, ibu hamil anemia, berat bayi lahir rendah 


\section{PENDAHULUAN}

A nemia merupakan salah satu masalah kesehatan di seluruh dunia terutama negara berkembang, diperkirakan 30 persen penduduk dunia menderita anemia. Anemia banyak terjadi pada masyarakat terutama pada ibu hamil. ${ }^{1}$ Menurut hasil Riskesdas 2018, prevalensi anemia ibu hamil di Indonesia yaitu 48,9 persen dengan penderita anemia berumur 15-24 tahun sebesar 84,6 persen dan penderita berumur 25-34 tahun sebesar 33,7 persen. Wanita mempunyai risiko terkena anemia paling tinggi. ${ }^{2}$

Defisiensi besi merupakan faktor utama yang bisa menyebabkan anemia, dan ini dapat terjadi pada siapapun, baik remaja putri, bayi, maupun wanita dewasa dan ibu hamil. Pada kehamilan, kadar hemoglobin yang rendah dapat terjadi sebagai fenomena fisiologis. Kebutuhan zat besi meningkat akibat permintaan yang lebih tinggi untuk mengakomodasi kebutuhan unit plasenta janin. Karenanya, anemia pada masa kehamilan dapat menyebabkan hasil kehamilan menjadi buruk dan bahkan kematian ibu. ${ }^{4}$ Hasil penelitian yang dilakukan oleh $\mathrm{Li}$, et al (2016) menunjukkan bahwa ada bukti kuat yang menunjukkan kejadian anemia pada saat kehamilan sangat memengaruhi proses pertumbuhan janin dalam kandungan dan bagaimana kelahirannya kelak, seperti kelahiran prematur, berat badan bayi lahir rendah, dan keadaan kesehatan lainnya. ${ }^{5}$

Anemia yang terjadi pada masa kehamilan dapat meningkatkan risiko buruknya hasil kehamilan atau bagaimana kondisi bayi yang dilahirkan, seperti kelahiran prematur, berat lahir rendah, ukuran kecil untuk usia kehamilan, kematian janin, dan anemia pada masa bayi. ${ }^{6}$ Berat bayi mencerminkan kesehatan dan status gizi ibu selama masa kehamilan. Pertumbuhan bayi dalam rahim ditentukan oleh faktor ibu, janin, dan plasenta. Selain itu, penyakit penyerta ibu selama kehamilan seperti anemia, hipertensi, diabetes juga dapat meningkatkan resiko BBLR. ${ }^{7}$ Kejadian BBLR di Indonesia sendiri memiliki prosentase sebesar6,2 persen dari seluruh bayi lahir pada tahun 2018, ${ }^{2}$ prosentase sebesar 6,1 persen dari seluruh bayi lahir di Jawa Tengah, ${ }^{2}$ dan pada tahun 2017 tercatat ada 3,9 persen dari seluruh bayi lahir di Kabupaten Sukoharjo. ${ }^{3}$
Protein dan komponen-komponen asam aminonya sangat bermanfaat untuk meningkatkan status gizi ibu hamil, sebab untuk mendukung pertumbuhan janin dalam kandungan diperlukan asupan zat gizi makro, seperti protein dan energi untuk meningkatkan nilai pertumbuhan janin ke arah positif, dan akan membuat bayi lahir dengan kondisi fisik yang baik. Namun masih banyak kasus KEK ditemukan dikalangan ibu hamil, hal ini dikarenakan masih rendahnya konsumsi protein dan energi. ${ }^{8}$ Padahal, hasil penelitian dari Switkowski, et al (2016) menunjukkan adanya hubungan antara asupan protein ibu saat hamil dengan berat bayi yang dilahirkannya. Semakin tinggi asupan protein ibu hamil, maka dapat menghindarkan kejadian berat bayi lahir. ${ }^{9}$ Menurut Muchtadi (2009), asupan protein seseorang sangat membantu dalam penyerapan zat besi, karena protein bekerjasama dengan rantai protein untuk mengangkut electron yang berperan dalam metabolisme energi. ${ }^{10}$ Rendahnya asupan protein (<16 persen energi dari protein) kemungkinan juga berhubungan dengan rendahnya kualitas tidur dan keinginan tidur seseorang. ${ }^{11}$

Menurut Murat, et al, (2015), seseorang yang mengalami anemia dengan kualitas tidur yang buruk dapat memperparah kondisi anemianya. Selain itu, kualitas tidur yang buruk pada penderita anemia juga dapat memicu terjadinya depresi dan penyakit psikologis lainnya jika tidak segera ditangani dengan cepat. ${ }^{12}$ Rata-rata penderita anemia mengalami kualitas tidur yang buruk, sehingga hal tersebut dapat memperparah kondisi anemianya. Indikator dari kualitas tidur adalah durasi waktu tidur, ketika seseorang bisa tertidur lelap..13 Durasi tidur dan buruknya pola tidur pada saat seseorang sedang hamil kemungkinan dapat meningkatkan faktor resiko yang memengaruhi hasil akhir kehamilan, seperti kondisi fisik bayi yang dilahirkan. ${ }^{14}$ Namun menurut Chang, et al, (2010), durasi tidur selama kehamilan belum tentu memengaruhi secara langsung hasil kehamilan, atau kondisi fisik maupun non fisik bayi, yang dilahirkan, seperti berat badan, panjang badan, maupun kondisi lahir cukup bulan atau prematurnya. ${ }^{15}$ Rata-rata ibu hamil, juga mengalami kualitas tidur yang buruk, selain karena masalah psikologis persiapan persalinan, kondisi ekonomi untuk 
mempersiapkan persalinan, serta dukungan keluarga yang kurang. Walaupun kualitas tidur sangat memengaruhi kondisi kesehatan ibu hamil, namun banyak ibu hamil dan keluarganya yang belum memahami serta menyadari hal tersebut, sehingga banyak yang mengabaikannya. ${ }^{16}$

Dugaan adanya hubungan kausal dari durasi tidur dan asupan protein ibu hamil anemia terhadap kejadian berat bayi lahir rendah, membutuhkan analisis jalur untuk pengujian teori tersebut benar apakah benar memiliki hubungan atau tidak. Seperti menurut Murti (2016), analisis jalur adalah analisis yang menguji suatu teori tentang suatu hubungan kausal antara tiga variabel atau lebih sebagaikelanjutan dari studi korelasi. ${ }^{17}$ Belum banyaknya studi dan penelitian yang mendalam tentang hubungan durasi tidur dan asupan protein pada ibu hamil yang mengalami anemia dengankejadian berat bayi lahir rendah dengan menggunakan analisis jalur, maka peneliti akan melakukan penelitian ini untuk membuktikan apakah ada hubungan secara langsung dan tidak langsung dari durasi tidur dan asupan protein pada ibu hamil anemia dengan kejadian berat bayi lahir rendah (BBLR).

\section{METODE PENELITIAN}

Penelitian ini telah dinyatakan layak secara etik oleh Komisi Etik Fakultas Kedokteran Universitas Sebelas Maret.Rancangan penelitian menggunakan desain Case Control. Penelitian dilaksanakan di wilayah Kabupaten Sukoharjo, tepatnya di wilayah Puskesmas Mojolaban, Puskesmas Baki, dan Puskesmas Grogol. Pemilihan tempat penelitian berdasarkan jumlah kasus ibu hamil anemia dan bayi BBLR terbanyak di Kabupaten Sukoharjo. Waktu penelitian dilaksanakan pada bulan April-Juni 2018.Sampel penelitian adalah ibu hamil anemia yang telah melahirkan tahun 2016-2018 di Kabupaten Sukoharjo, dibagi menjadi dua kelompok, yaitu kelompok kontrol adalah yangmelahirkan bayi dengan berat badan normal, dan kelompok kasus adalah yang melahirkan bayi dengan berat badan lahir rendah.

Pada penelitian dengan model Case Control maka yang dibutuhkan adalah jumlah untuk kelompok kontrol dan kelompok kasus. Dari penghitungan sampel menurut rumus penghitungan sampel model Case Control dari Notoatmodjo (2012) ${ }^{18}$ didapatkan hasil 37,30 yang kemudian dibulatkan menjadi 37 , dengan perbandingan kelompok kontrol : kelompok kasus adalah 2 : 1 , sehingga dapat dikelompokkan bahwa akan ada 74 orang dalam kelompok kontrol dan 37 orang dalam kelompok kasus. Total sampel adalah 111 orang.

Cara pengambilan sampel penelitian ini menggunakan teknik Purposive sampling. Penarikan sampel secara purposive merupakan cara penarikan sampel yang dilakukan memilih subjek berdasarkan kriteria spesifik yang ditetapkan peneliti. Dimana ditentukan kriteria inklusi sebagai berikut: Ibu hamil anemia yang telah melahirkan pada tahun 2016-2018 di Kabupaten Sukoharjo dan tidak mengalami obesitas saat kehamilan, berusia 20-30 tahun saat hamil, danmelahirkan dengan cukup bulan (tidak prematur). Selain itu juga ditentukan kriteria eksklusi sebagai berikut: dijumpai penyakit berat selain anemia saat kehamilan, dan ibu/bayi dalam keadaan meninggal dunia.

Variabel bebas penelitian ini adalah durasi tidur dan asupan protein ibu hamil anemia, dimana kualitas tidur adalah variabel antara, dan kejadian berat bayi lahir rendah adalah variabel terikat. Instrumen penelitian meliputi form FFQ-SQ untuk melihat bagaimana frekuensi asupan makanan subyek penelitian selama hamil sampai melahirkan, terutama asupan proteinnya. Data kemudian diolah dengan Nutrisurvey 2007 untuk melihat berapa total juga frekuensi konsumsi aspan proteinnya.Form data ibu hamil yang berisi tentang data-data penting subyek yang nantinya akan diolah peneliti sebagai bahan penelitian dan membuat kesimpulan dari penelitian ini. Serta form PSQI dalam Bahasa Indonesia telah diuji validitas dengan menggunakan teknik korelasi product moment dan uji Cronbach (Cronbach Alpha) dengan menggunakan program statistik. Hasil spesifitas adalah $86,5 \%$, sensifitas $89,6 \%$, dan dengan validitas dari uji Cronbach Alpha sebesar 0,83, untuk melihat durasi dan menilai kualitas tidursubyek selama hamil. Durasi tidur dihitung per-jam tidur malam subyek, sedangkan kualitas tidur dihitung sesuai dengan perhitungan dalam form PSQI.Analisis data menggunakan analisis jalur dengan software SPSS Ver.21. 
Variabel perancu dalam penelitian ini adalah usia dan berat badan ibu saat hamil, serta usia dan riwayat kehamilan. Kontrol variabel perancu dilakukan dengan cara kontrol restriksi, dimana peneliti membatasi karakteristik sampel penelitian dalam kriteria inklusi.

\section{HASIL}

Hasil penelitian menunjukkan subyek sejumlah 111 orang. Hampir setengah dari total seluruh subyek penelitian adalah ibu rumah tangga, sejumlah 64 orang $(57,65 \%)$. Kategori subyek yang wiraswasta berjumlah 8 orang $(7,20 \%)$. Subyek yang bekerja sebagai karyawan ada 33 orang $(29,62 \%)$. Kategori guru/dosen ada 4 orang (3,60\%). Mahasiswa ada 2 orang $(1,80 \%)$.Sejumlah 51 orang $(45,94 \%)$ dari total seluruh subyek berpendidikan terakhir SMA/SMK dan setara. Sebanyak 36 orang $(32,43 \%)$ berpendidikan terakhir SMP, 12 orang $(10,81 \%)$ berpendidikan terakhir S1/D4, 8 orang $(7,20 \%)$ berpendidikan terakhir SD, 2 orang $(1,80 \%)$ berpendidikan terakhir Diploma (D1/2/3), dan terakhir 2 orang $(1,80 \%)$ berpendidikan terakhir S2 (Tabel 1).

Sebanyak 56 (75,68\%) subyek pada kelompok kontrol yang melahirkan bayi dengan berat badan normal mengkonsumsi makanan dan minuman dengan kandungan protein hewani tinggi seperti daging, susu, dan telur secara harian, sebanyak $8(10,81 \%)$ secara mingguan, dan sebanyak $10(13,51 \%)$ secara bulanan, selama mereka hamil. Sedangkan pada kelompok kasus yang melahirkan bayi dengan berat badan rendah ada 2 (5,41\%) subyek yang mengkonsumsi makanan dan minuman dengan kandungan protein hewani tinggi seperti daging, susu, dan telur secara harian, secara mingguan ada $3(8,11 \%)$, secara bulanan ada $10(27,03 \%)$, dan yang selama hamil hanya sekali atau dua kali bahkan tidak pernah sama sekali ada $22(59,46 \%)$.Subyek yang memiliki pemasukan keluarga $\mathrm{Rp} 0,00$ Rp 1.000.000,00 sebanyak 19 (17,12\%), Rp $1.100 .000,00$ - Rp 2.000.000,00 sebanyak 77 (69,37\%), Rp 2.100.000,00 - Rp 3.000.000,00 sebanyak 9 (8,11\%), dan > Rp 3.000.000,00 sebanyak 6 (5,41\%). Upah Minimum Kerja
(UMK) di Kabupaten Sukoharjo sendiri sebesar Rp 1.600.000,00 (Tabel 1).

Sebanyak 49 (44,14\%) subyek baru pertama kali hamil, $36(32,43 \%)$ subyek sudah dua kali hamil, $16(14,41 \%)$ subyek sudah tiga kali hamil, 6 orang $(5,40 \%)$ subyek sudah empat kali hamil, dan sisanya 4 (3,60\%) subyek pernah hamil lebih dari empat kali. Sebanyak 99 $(89,19 \%)$ subyek belum atau tidak pernah mengalami keguguran dan sisanya $12(10,81 \%)$ subyek pernah sekali mengalami keguguran dalam riwayat seluruh kehamilannya. Dari hasil penelitian didapatkan bahwa semua subyek melahirkan dalam hitungan cukup bulan, yaitu antara 37 sampai 42 bulan. Tidak ada subyek yang melahirkan kurang bulan, prematur, maupun lebih bulan (Tabel 1).

Sebanyak 50 (67,57\%) subyek pada kelompok kontrol yang melahirkan bayi dengan berat badan normal mengonsumsi makanan dengan kandungan protein nabati tinggi seperti tahu, tempe, dan bayam secara harian, sebanyak $20(27,03 \%)$ secara mingguan, dan sebanyak $4(5,41 \%)$ secara bulanan, selama mereka hamil. Sedangkan pada kelompok kasus yang melahirkan bayi dengan berat badan rendah ada $30(81,08 \%)$ subyek yang mengonsumsi makanan dengan kandungan protein nabati tinggi seperti tahu, tempe, dan bayam secara harian, dan secara mingguan ada 7 (18,92\%). Pada kelompok kontrol ada 5 $(3,70 \%)$ subyek yang memiliki durasi tidur selama hamil $<5$ jam, $29(21,46 \%)$ subyek $5-7$ jam, dan $40 \quad(29,60 \%)$ subyek $>7$ jam. Sedangkan pada kelompok kasus ada 2 $(0,74 \%)$ subyek memiliki durasi tidur selama hamil <5 jam, $17(6,29 \%)$ 5-7 jam, dan 18 $(6,66 \%)>7$ jam(Tabel 2).

Hasil identifikasi model analisis jalur dengan uji bivariat Korelasi Pearson menunjukkan bahwa $p$ value tiap variabel adalah $p \geq 0,05$ (Tabel 3), dimana artinya model analisis jalur ini bisa dikatakan fit atau sesuai.Hasil analisis jalur menunjukkan hubungan asupan protein dengan durasi tidur ibu hamil anemia mempunyai nilai $(p=0,415)$, yang artinya tidak ada hubungan signifikan, hubungan durasi tidur dengan kualitas tidur ibu hamil anemia mempunyai nilai $(p=0,030)$ yang artinya ada hubungan signifikan, hubungan asupan protein dengan kualitas tidur ibu hamil anemia menunjukkan nilai $(p=0,706)$ yang artinya tidak ada hubungan signifikan, 
hubungan durasi tidur ibu hamil anemia dengan berat badan lahir bayi $(p=0,285)$ yaitu artinya tidak ada hubungan secara signifikan, hubungan asupan protein dengan berat badan lahir bayi adalah $(p=0,019)$ yang artinya ada hubungan signifikan, dan hubungan kualitas tidur dengan berat badan lahir bayi $(p=0,379)$ yang artinya tidak ada hubungan signifikan (Tabel 4 dan Gambar 1).

Tabel 1

Karakteristik Ibu Hamil Anemia

\begin{tabular}{lr}
\hline Karakteristik Ibu & (\%) \\
\hline Pekerjaan & \\
lbu Rumah Tangga & $64(57,65)$ \\
Karyawan & $33(29,72)$ \\
Wiraswasta & $8(7,20)$ \\
Mahasiswa & $2(1,80)$ \\
Guru/Dosen & $4(3,60)$ \\
Pendidikan & \\
SD & \\
SMP & $8(7,20)$ \\
SMA/SMK & $36(32,43)$ \\
D1/D2/D3 & $51(45,94)$ \\
S1/D4 & $2(1,80)$ \\
S2 & $12(10,81)$ \\
Pemasukan Tiap Bulan & $2(1,80)$ \\
Rp 0,00 - Rp 1.000.000,00 & \\
Rp 1.100.000,00 - Rp 2.000.000,00 & \\
Rp 2.100.000,00 - Rp 3.000.000,00 & $19(17,12)$ \\
$>$ Rp 3.000.000,00 & $77(69,37)$ \\
Riwayat Keguguran & $9(8,11)$ \\
0 & $6(5,41)$ \\
1 & \\
Riwayat Kehamilan & \\
1 & $99(89,19)$ \\
2 & $12(10,81)$ \\
3 & \\
4 & \\
$>4$ & $49(44,14)$ \\
\hline & $36(32,43)$ \\
& $16(14,41)$ \\
& $6(5,40)$ \\
& $4(3,60)$ \\
\hline
\end{tabular}


Tabel 2

Karakteristik Ibu Hamil pada Kasus dan Kontrol

\begin{tabular}{lcrcr}
\hline Karakteristik Ibu & Kontrol (\%) & \multicolumn{2}{c}{ Kasus (\%) } \\
\hline Mengonsumsi Protein Hewani & $56(41,44)$ & & 2 & $(0,74)$ \\
Harian & 8 & $(5,92)$ & 3 & $(1,11)$ \\
Mingguan & 10 & $(7,40)$ & 10 & $(3,70)$ \\
Bulanan & & - & 22 & $(8,14)$ \\
Hampir Tidak Pernah & & & & \\
Mengonsumsi Protein Nabati & $50(37,00)$ & $30(11.10)$ \\
Harian & $20(14,80)$ & 7 & $(2,59)$ \\
Mingguan & $4(2,96)$ & & & - \\
Bulanan & & & & \\
Durasi Tidur & $5(3,70)$ & 2 & $(0,74)$ \\
<5 Jam & $29(21,46)$ & 17 & $(6,29)$ \\
5-7 Jam & $40(29,60)$ & 18 & $(6,66)$ \\
$>7$ Jam & & & & \\
\hline
\end{tabular}

Tabel 3

Hasil Korelasi Pearson Hubungan Tiap Variabel

\begin{tabular}{lclc}
\hline Hubungan Antar Variabel & $\mathbf{r}$ & $\mathbf{C l}(95 \%)$ & $\mathbf{p}$ \\
\hline Asupan Protein dengan Kejadian BBLR & 0,157 & $-0,033$ sampai 0,316 & 0,100 \\
Asupan Protein dengan Durasi Tidur & $-0,078$ & $-0,248$ sampai 0,108 & 0,414 \\
Asupan Protein dengan Kualitas Tidur & 0,100 & $-0,122$ sampai 0,305 & 0,296 \\
Durasi Tidur dengan Kualitas Tidur & $-0,150$ & $-0,363$ sampai 0,046 & 0,117 \\
Durasi Tidur dengan Kejadian BBLR & $-0,109$ & $-0,256$ sampai 0,056 & 0,255 \\
Kualitas Tidur dengan Kejadian BBLR & $-0,087$ & $-0,269$ sampai 0,096 & 0,366 \\
\hline
\end{tabular}

Tabel 4

Hasil Analisis Jalur Hubungan Durasi Tidur dan Asupan Protein pada Ibu Hamil Anemia dengan Kejadian Berat Bayi Lahir Rendah

\begin{tabular}{lccc}
\hline Hubungan Antar Variabel & B & Cl (95\%) & p \\
\hline Hubungan Langsung & & & \\
Asupan Protein dengan Kejadian BBLR & 0,224 & 0,001 sampai 0,006 & 0,019 \\
$\begin{array}{l}\text { Durasi Tidur dengan Kejadian BBLR } \\
\text { Hubungan Tidak Langsung }\end{array}$ & 0,101 & $-0,024$ sampai 0,081 & 0,285 \\
Asupan Protein dengan Durasi Tidur & $-0,078$ & $-5,859$ sampai 2,428 & 0,414 \\
Asupan Protein dengan Kualitas Tidur & 0,036 & $-0,016$ sampai 0,023 & 0,706 \\
Durasi Tidur dengan Kualitas Tidur & $-0,208$ & $-0,890$ sampai -0,047 & 0,030 \\
Kualitas Tidur dengan Kejadian BBLR & 0,083 & $-0,014$ sampai 0,035 & 0,379 \\
\hline
\end{tabular}




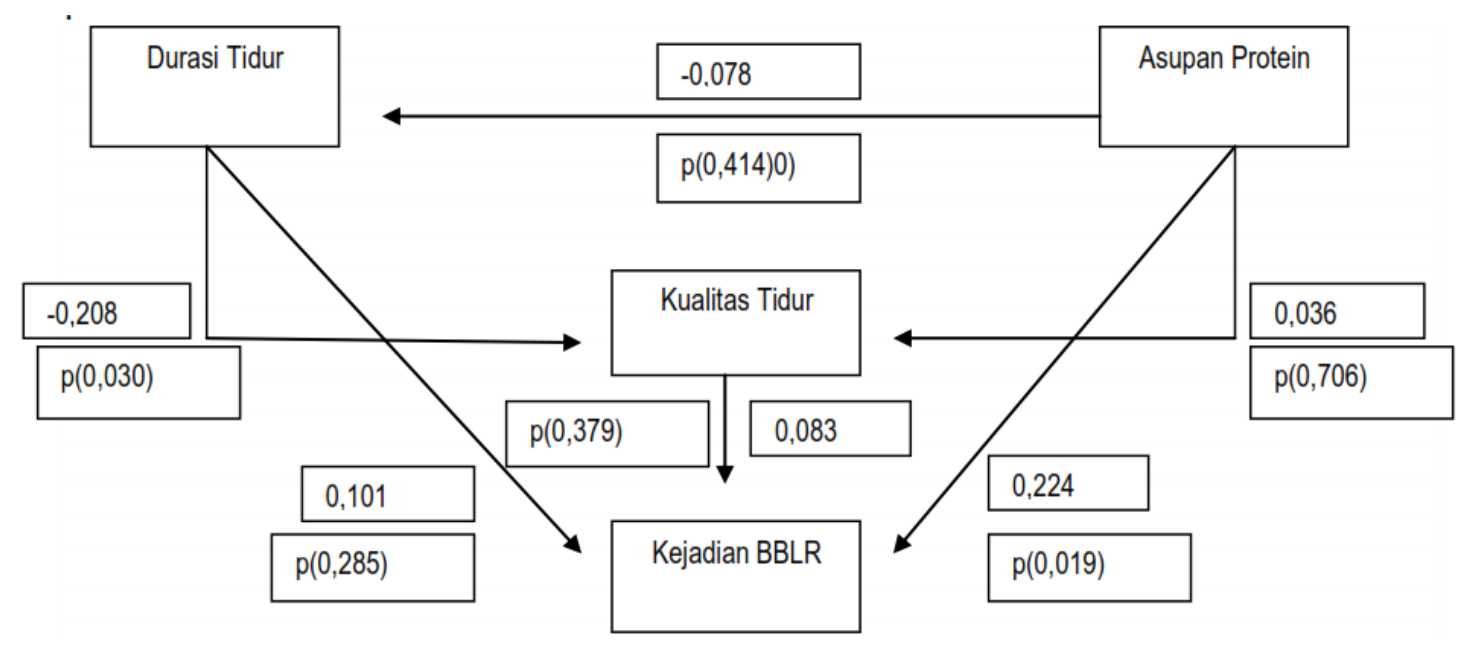

Gambar 1

Hasil Uji Path Analysis Hubungan Durasi Tidur dan Asupan Protein Ibu Hamil Anemia dengan kejadian berat bayi lahir rendah (BBLR)

\section{BAHASAN}

Hubungan Langsung Durasi Tidur dan Asupan Protein Ibu Hamil Anemia dengan Kejadian Berat Bayi Lahir Rendah

Secara langsung durasi tidur ibu hamil anemia dengan berat badan lahir bayi tidak memiliki hubungan signifikan.Hal ini seperti disebutkan oleh Chang, et al, (2010), durasi tidur selama kehamilan memiliki hubungan secara langsung lama waktu persalinan, angka operasi sesar yang lebih tinggi, dan tingkat depresi ibu hamil. Durasi tidur belum memengaruhi secara langsung hasil kehamilan, atau kondisi fisik maupun non fisik bayi, yang dilahirkan, seperti berat badan, panjang badan, maupun kondisi lahir cukup bulan atau prematurnya. ${ }^{15}$

Hasil penelitian ini tidak sejalan dengan penelitian dari $\mathrm{Xu}$, et al (2017) tentang durasi tidur ibu hamil yang dapat memengaruhi kesehatan fisik bayi yang dilahirkan, kemungkinan hal tersebut karena perbedaan pekerjaan dari subyek serta kondisi ekonomi daerah penelitian, dimana pada penelitian tersebut semua subyeknya adalah ibu hamil yang bekerja sebagai buruh pabrik yang tinggal di daerah miskin dan kumuh, sedangkan pada penelitian ini sebagian besar subyek adalah ibu hamil anemia yang berada di rumah atau ibu rumah tangga yang tinggal di daerah dengan lingkungan bersih dan memiliki status ekonomi menengah ke atas. ${ }^{16}$

Selain itu, walaupun subyek semua melahirkan dalam kondisi cukup bulan (tidak prematur), masih tetap bisa terjadi berat bayi lahir rendah karena berbagai faktor yang memhubungani.Pada kondisi lahir cukup bulan, berat badan bayi lahir rendah juga masih bisa terjadi karena kondisi janin yang mengalami gangguan akibat gizi buruk yang terjadi pada ibu, serta bisa juga diakibatkan oleh keadaan tingkat sosial ekonomi orangtua yang rendah. BMI ibu di masa sebelum kehamilan, kenaikan berat badan, dan kadar $\mathrm{Hb}$ saat hamil juga memhubungani bagaimana berat badan bayi saat dilahirkan nantinya. ${ }^{19}$ Status gizi ibu sebelum dan selama hamil dapat memengaruhi pertumbuhan janin yang sedang dikandung. Bila status gizi ibu normal pada masa sebelum dan selama hamil, kemungkinan besar akan melahirkan bayi yang sehat, cukup bulan, dengan berat badan normal. ${ }^{6}$

Hasil penelitian dari Switkowski, et al (2016) menunjukkan adanya hubungan antara asupan protein ibu saat hamil dengan berat bayi yang dilahirkannya.Semakin tinggi asupan protein ibu hamil, maka dapat menghindarkan kejadian berat bayi lahir. Asupan protein ibu hamil anemia secara langsung dengan berat badan lahir bayi memiliki hubungan langsung yang signifikan dan positif yang artinya semakin 
besar asupan protein maka memengaruhi berat badan lahir bayi secara positif. ${ }^{9}$

Protein dan komponen-komponen asam aminonya sangat bermanfaat untuk meningkatkan status gizi ibu hamil, sebab saat itu janin mengalami pertumbuhan dengan sangat cepat sehingga membutuhkan asupan zat gizi makro, seperti protein dan energi untuk meningkatkan nilai pertumbuhan janin ke arah positif, dan akan membuat bayi lahir dengan kondisi fisik yang baik. ${ }^{8}$ Asupan protein seseorang sangat membantu dalam penyerapan zat besi, karena protein bekerjasama dengan rantai protein untuk mengangkut elektron yang berperan dalam metabolisme energi. ${ }^{10}$ Menurut Briawan (2014), seseorang perlu meningkatkan asupan zat besi atau makanan yang dapat membantu penyerapan zat besi untuk menghindari atau menyembuhkan anemianya. ${ }^{20}$

Berdasarkan hasil wawancara dengan subyek melalui form FFQ-SQ didapatkan data bahwa 22 dari 37 subyek kelompok kasus yang melahirkan bayi dengan berat badan rendah jarang (masuk dalam hitungan bulanan) bahkan tidak pernah sama sekali selama hamil mengonsumsi makanan yang mengandung protein hewani seperti daging ayam, susu, daging sapi, telur, dan ikan. Mereka lebih banyak mengkonsumsi makanan seperti tempe, ikan asin, buah pisang, bayam, dan kubis. Sedangkan yang rutin secara harian mengkonsumsi makanan yang mengandung protein hewani justru 56 dari 74 subyek kelompok kontrol yang melahirkan bayi dengan berat badan normal. Hal ini sejalan dengan hasil penelitian Anisa, et al (2011), bahwa ibu hamil yang kekurangan asupan protein hewani (seperti daging, susu, dan telur), asam folat, dan zat besi mengalami risiko lebih besar melahirkan bayi dengan berat badan rendah. ${ }^{21}$

Berdasarkan hasil penelitian Retni, et al (2016), konsumsi lauk pauk yang mengandung protein hewani seperti daging, susu, dan telur yang sangat kurang pada saat ibu sedang mengandung ternyata sangat berkaitan dengan kejadian berat bayi lahir rendah. Hal ini dikarenakan tidak terpenuhinya zat besi yang banyak terdapat di dalam protein hewani, seperti daging dan ikan, padahal zat besi sangat penting untuk kesehatan ibu hamil dan pertumbuhan janin di dalam kandungan. Konsumsi makanan yang tidak memiliki ragam zat gizi di dalam satu piringnya akan menyebabkan ketidakseimbangan asupan gizi ibu hamil dan janin yang dikandung. ${ }^{22}$

Faktor penyebab terjadinya anemia pada seseorang secara umum menurut Briawan (2014) adalah karena rendahnya asupan zat besi. ${ }^{20}$ Anemia defisiensi besi pada ibu dapat memengaruhi pertumbuhan dan perkembangan janin/bayi saat kehamilan maupun setelahnya. ${ }^{23} \mathrm{bu}$ hamil dengan kadar hemoglobin kurang dari $11 \mathrm{gm} / \mathrm{dl}$ secara bermakna berhubungan dengan kelahiran bayi BBLR. ${ }^{24} J u m l a h$ bayi berat lahir rendah $(64 \%)$ secara statistik lebih tinggi secara signifikan ( $p$ $<0,001)$ pada kelompok ibu anemia daripada kelompok non-anemia (10\%). ${ }^{25}$ Wanita anemia memiliki lebih tinggi risiko melahirkan bayi BBLR dibandingkan wanita non-anemia, yakni sebesar 1,25 kali.. ${ }^{26}$ Anemia selama kehamilan memiliki 1,51 kali risiko lebih tinggi untuk melahirkan bayi BBLR dengan $P<0,01 .{ }^{27}$

\section{Hubungan Tidak Langsung (Melalui Kualitas Tidur) Durasi Tidur dan Asupan Protein Ibu Hamil Anemia dengan Kejadian Berat Bayi Lahir Rendah}

Durasi dan kualitas tidur ibu hamil anemia memiliki hubungan yang signifikan, karena adanya keterikatan antara keduanya.Indikator dari kualitas tidur adalah durasi waktu tidur, ketika seseorang bisa tertidur lelap. ${ }^{13}$ Namun, hubungan tersebut menunjukkan angka negatif karena semakin tinggi nilai kuesioner kualitas tidur (PSQI) maka semakin buruk kualitas tidurnya, dan sebaliknya.Sehingga semakin panjang durasi tidurnya maka semakin memengaruhi besar nilai kuesioner kualitas tidurnya.

Kualitas tidur dinilai dengan menggunakan Indeks Kualitas Tidur Pittsburg (PSQI) yang telah divalidasi. PSQI adalah kuesioner yang memiliki 19 item yang akan menjadi bahan evaluasi bagaimana kualitas tidur seseorang pada rentang waktu sebulan terakhir. PSQI menghasilkan tujuh komponen tidur yang terkait dengan kebiasaan tidur seperti durasi tidur, efisiensi tidur, penggunaan obat tidur, disfungsi siang hari, serta kualitas tidur secara keseluruhan. Dimana ada nilai $0-21$, yaitu semakin besar angka nilainya maka semakin buruk kualitas tidurnya. ${ }^{28}$

Asupan protein dan durasi tidur tidak memiliki hubungan signifikan dengan kualitas 
tidur ibu hamil anemia. Hal ini seperti juga diungkapkan oleh Onge, et al (2016), bahwa asupan makronutrien meliputi karbohidrat, lemak, energi, dan protein memiliki hubungan yang kecil terhadap kondisi REM (rapid eye movement) tidur manusia, namun belum bisa dipastikan dengan jelas memengaruhi durasi, pola, dan kualitas tidur karena ada berbagai faktor lain yang menjadi rancu. Beberapa makanan tertentu seperti susu, buah, sayur, dan ikan dapat memberikan efek pada kondisi tidur, namun bukan dalam jangka waktu lama. Sehingga bisa dikatakan kurang mampu memengaruhi kualitas tidur seseorang dalam jangka waktu lama. ${ }^{11}$

Hubungan yang tidak signifikan dari asupan protein dengan durasi dan kualitas tidur ibu hamil sejalan dengan penelitian kohort yang dilakukan oleh Nagashima, et al (2017) bahwa asupan protein dan suplementasi asam amino esensial yang diberikan pada subyek ibu hamil dan orang dewasa tidak memiliki hubungan dengan durasi dan kualitas tidurnya. ${ }^{29}$

Kualitas tidur ibu hamil anemia dan berat badan lahir bayi memiliki nilai positif namun tidak memiliki hubungan signifikan. Hal ini sejalan dengan penelitian Song (2014), bahwa durasi dan kualitas tidur ibu saat hamil, baik ibu sehat maupun anemia, tak memiliki hubungan langsung yang signifikan dengan kejadian berat bayi lahir rendah. ${ }^{30}$

\section{SIMPULAN DAN SARAN}

\section{Simpulan}

Tidak ada hubungan secara langsung dari durasi tidur pada ibu hamil anemia dengan kejadian BBLR, tidak ada hubungan secara tidak langsung (melalui kualitas tidur) antara durasi tidur pada ibu hamil anemia dengan kejadian BBLR. Durasi dan kualitas tidur ibu hamil anemia memiliki hubungan signifikan. Ada hubungan secara langsung asupan protein pada ibu hamil anemia dengan kejadian BBLR.Tidak ada hubungan secara tidak langsung (melalui kualitas tidur) dari asupan protein pada ibu hamil anemia dengan kejadian BBLR.

\section{Saran}

Hasil penelitian ini sebagai masukan bagi setiap ibu hamil dan keluarga untuk lebih memerhatikan asupan makan dan kebiasaan tidur ibu hamil, terutama yang memiliki kondisi anemia. Ibu hamil perlu aktif untuk mengonsultasikan masalah asupan makanan terutama sumber protein, kondisi kesehatan, dan kebiasaan tidurnya saat hamil, dan pihak keluarga juga aktif memberikan dorongan serta motivasi.

Penelitian ini juga bisa menjadi masukan untuk program pemerintah dalam menanggulangi kasus BBLR karena anemia saat masa kehamilan, yaitu dengan memaksimalkan program penyuluhan, promosi, dan pendidikan gizi terutama tentang pentingnya asupan makanan sumber protein bagi ibu hamil.

\section{RUJUKAN}

1. World Health Organization. World Health Statistic. United State of America; 2013.

2. Kemenkes RI. Riset Kesehatan Dasar. Jakarta: Kementerian Kesehatan Republik Indonesia; 2018.

3. Dinas Kesehatan Kabupaten Sukoharjo. Profil Kesehatan Tahun 2017. Sukoharjo: Dinas Kesehatan Kabupaten Sukoharjo; 2017.

4. Susanti. Low Hemoglobin among Pregnant Women in Midwives Practice of Primary Health Care, Jatinangor, Indonesia: Iron Deficiency Anemia or $\beta$-Thalassemia Trait. UMY Open Access Journals 2017; $1-5$.

5. Li, S., Gao, X., Wei, Y., Zhu, G.,and Yang, C. The Relation Between Iron Deficiency and Thyroid Fuction in Chinese Women during Early Pregnancy. J Nutr Sci Vitamino 2016; I(62) 397401 (doi: 10.3177/jnsv.62.397).

6. Adriani, M dan Wirjatmadi, B. Peranan Gizi dalam Siklus Kehidupan. Jakarta: Kencana Prenadamedia Group; 2014.

7. Khan, Nasrullah, and Jaleel. Frequency and risk factors of low birth weight in term pregnancy. Pak J Med Sci 2016; 32(1), 138-142 (doi: 10.12669/pjms.321.8120).

8. Arkkola, T. Diet during pregnancy: Diettary pattern and weight gain rate among finnish pregnant women. Universitasis Ouluensis, D medika 2009; 1037.

9. Switkowski, KM., Jaqcues, PF., Must, A., Kleinman, KP., Gillman, MW., and Oken, PE. Maternal protein intake during pregnancy and linear growth in the offspring. The American Journal of Clinical Nutrition 2016; 104(4), 11281136.

10. Muchtadi, D. Pengantar IImu Gizi. Bandung; Alfabeta; 2009.

11. Onge, MPS., Mikic, A., and Pietrolungo, CE. Effect of Diet on Sleep Quality. American 
Society of Nutrition Adv Nutri, 7,938-49, Doi: 10.3945/an.116.012336 (2016).

12. Murat, S., Ali, U., Serdal, K., and Suleyman, D. Assessment of subjective sleep quality in iron deficiency anaemia. African Health Sciences 2015; 15(2), 621-7, (doi: 10.4314/ahs.v15i2.40).

13. Bertolazi, AN., Fagondes, SC., Hoof, L., Dartora, EG., Miozzo, IC., Barba, ME., et al. Validation of the Brazilian Portuguese version of the Pittsburgh Sleep Quality Index. Sleep Med 2011; 12(1), 70-5 (doi: 10.1016/j.sleep.2010.04.020).

14. Xu, K., Liu, H., Bai, M.,and Gao, J. Redox Properties of Tryptophan Metabolism and the Concept of Tryptophan Use in Pregnancy. Int J Sci 2017; 18(7), 1595 (doi:10.3390/ijms.180715959).

15. Chang, JJ., Pien, GW., Duntley, SP., and Macones, GA. Sleep Deprivation During Pregnancy and Maternal and Fetal Outcomes: Is There A Relationship?. HHS Public Access. Sleep Med Rev 2017; 14(2), 107-14 (doi: 10.1016/j.smrv.2009.05.001).

16. Xu, X., Liu, D., Zhang, Z., and Sharma, M. Sleep Quality: Sleep Duration and Quality in Pregnant Women: A Cross-Sectional Survey in China.Int J Environ Res Public Health 2017; 14(7), 817(doi: 10.3390/ijerph.14070817).

17. Murti, Bhisma. Prinsip dan Metode Riset Epidemiologi. Surakarta: Universitas Sebelas Maret; 2016

18. Notoatmodjo, S. Metodologi Penelitian Kesehatan. Jakarta: Rineka Cipta; 2012.

19. Yadav and Lee. Maternal Factors in Predicting Low Birth Weight Babies. Med Journal Malaysia 2013; 68(1), 48-7.

20. Briawan, D. Anemia Masalah Gizi Pada Remaja Wanita. Jakarta; EGC; 2014.

21. Anisa, M., Duranni, and Anjali, R. Effect of maternal dietary intake on the weight of the newborn in Aligarh city, India. Nigerian Medical Journal 2011; 52(30), 177-81.

22. Retni, Margawati, A., dan Widjanarko, B. Hubungan status gizi dan asupan gizi ibu terhadap berat bayi lahir rendah pada kehamilan usia remaja. J Gizi Indonesia 2016; 5(1), 14-19 (doi: 10.14710/jgi.5.1.14-19).
23. Kemenkes Rl. Buku Saku Pemantauan Status Gizi dan Indikator Kinerja Gizi Tahun 2015. Jakata: Direktorat Gizi Masyarakat Direktorat Jenderal Kesehatan Masyarakat Kementerian Kesehatan Rl; 2016.

24. Sharma, SR., Smith, G., Utsav, T., Sanjiv, SB., Basyal, B., Wagle., K., et al. Low birth weight at term and its determinants in a tertiary hospital of nepal: a case-control study. Plos One 2015; 10(4): $\quad$ e0123962 (doi: 10.1371/journal.pone.0123962).

25. Ahmad, MO., Kalsoom, U., Sughra, U., Hadi, U, and Imran, M. Effect of maternal anaemiaon birth weight. J Ayub Med Coll Abbottabad, 23(1), 77-9 (2011).

26. Bian, Y., Zhang, Z., Liu, Q., and Wu, D. Maternal risk factors for low birth weight for term births in a developed region in china: a hospitalbased study of 55,633 pregnancies. Journal Biomedical of Research 2013; 27(1), 14-22 (doi: 10.7555/JBR.27.20120046).

27. Yi, SW., Han, Y., and Ohrr, H. Anemia before pregnancy and risk of preterm birth, low birth weight and small-for-gestational-age birth in korean women. European Journal of Clinical Nutrition 2013; 67, 337-342 (doi: 10.1038/ejcn.2013.12)

28. Sanchez, SE., Martinez, C., Oriol, RA., Yanez, D., Cataneda, B., Sanchez, E.,et al. Sleep Quality, Sleep Patterns and Consumption of Energy Drinks and Other Caffeinated Beverages among Peruvian College Students. Health (Irvine Calif) 2013; 5(8B),26-35 (doi:10.4236/health.2013.58A2005).

29. Nagashima, SM., Yamashita, M., Tojo, C., Kondo, M.,Morita, T., and Wakamura, T. Can Tryptophan Supplement Intake at Breakfast Enhance Melatonin Secretion at Night?. Journal of Psycological Anthropology 2017; 36(20) (doi: 10.1186/s40101-017-0135-9).

30. Song, Lulu. Healthy Baby Cohort in China. Naps During Pregnancy May Be Linked With Healthier Baby Weight.London: Reuters; 2014. 